\title{
PENINGKATAN KEMAMPUAN BERPIKIR KRITIS DAN HASIL BELAJAR MELALUI PEMANFAATAN MEDIA PEMBELAJARAN BERBASIS VIDEO PROSHOW GOLD PADA SISWA SEKOLAH DASAR
}

\author{
Heldie Bramantha \\ Universitas Abdurachman Saleh Situbondo \\ E-mail: heldie_bramantha@unars.ac.id \\ Received:Apr 23, 2020 Revised: Apr 26, 2020 Accepted: Apr 30, 2020
}

\begin{abstract}
Abstrak
Penelitian ini bertujuan untuk mengetahui peningkatan kemampuan berfikir kritis dan hasil belajar melalui penggunaan media pembelajaran berbasis video Proshow Gold pada siswa kelas 4 di SD Negeri 3 Mangaran kabupaten Situbondo. Subyek penelitian adalah kelas 4 SDN 3 Mangaran yang berjumlah 19 orang. Jenis penelitian yang yang digunakan adalah penelitian tindakan kelas (PTK) model Kemmis dan Mc Taggart, satu siklus terdiri dari 4 tahapan, yaitu perencanaan, pelaksanaan, observasi, dan refleksi. Teknik pengumpulan data yaitu berupa observasi, wawancara, tes, dan dokumentasi. Sedangkan proses analisi data penilitian ini menggunakan analisis deskriptif persentase aktivitas guru, berpikir kritis dan hasil belajar siswa. Hasil yang diperoleh dalam penelitian ini menunjukkan adanya peningkatan berpikir kritis dan hasil belajar siswa. Pada kemampuan kritis di siklus 1 sebesar 63\% siswa yang mengalami ketuntasan dalam mengerjakan kuis. Pada tahap siklus 2 sebesar $84 \%$ siswa yang mengalami ketuntasan dalam mengerjakan kuis sehingga penelitian dihentikan. Sedangkan hasil belajar pada kegiatan sebelumnya sebesar $44 \%$ siswa yang mengalami ketuntasan. Pada siklus 1, hasil belajar siswa mengalami peningkatan menjadi $68 \%$ siswa yang mengalami ketuntasan belajar dalam ulangan harian. Dari tahap pra siklus ke siklus terdapat peningkatan. Pada siklus 2, hasil belajar siswa mengalami peningkatan menjadi $89 \%$ siswa yang mengalami ketuntasan hasil belajar sehingga penelitian di hentikan. Berdasarkan data tersebut dapat disimpulkan bahwa media pembelajaran berbasis video Proshow Gold dapat meningkatkan kemampuan berpikir kritis dan hasil belajar pada siswa kelas 4 SD Negeri 3 Mangaran Kabupaten Situbondo.
\end{abstract}

Kata Kunci: video Proshow Gold, media pembelajaran, berpikir kritis, hasil belajar 


\section{Abstract \\ IMPROVING CRITICAL THINKING ABILITIES AND LEARNING OUTCOMES THROUGH THE UTILIZATION OF PROSHOW GOLD VIDEO-BASED LEARNING MEDIA IN CLASS 4 STUDENTS IN SD NEGERI 3 MANGARAN}

This study aims to determine the increase in critical thinking skills and learning outcomes through the use of Proshow Gold video-based learning media for grade 4 students at SD Negeri 3 Mangaran, Situbondo district. The research subjects were grade 4 SDN 3 Mangaran, amounting to 19 people. The type of research used is a classroom action research (PTK) model of Kemmis and Mc Taggart, one cycle consisting of 4 stages, namely planning, implementing, observing, and reflecting. Data collection techniques are in the form of observation, interviews, tests, and documentation. While the data analysis process of this research uses descriptive analysis of the percentage of teacher activity, critical thinking and student learning outcomes. The results obtained in this study indicate an increase in critical thinking and student learning outcomes. The critical ability in cycle 1 was $63 \%$ of students who experienced completeness in doing quizzes. At the stage of cycle 2, 84\% of students experienced completeness in taking the quiz so that the research was stopped. While the learning outcomes in the previous activities amounted to $44 \%$ of students who experienced completeness. In cycle 1, student learning outcomes increased to $68 \%$ of students who experienced learning completeness in daily tests. From the pre-cycle stage to the cycle there is an increase. In cycle 2, student learning outcomes increased to $89 \%$ of students who experienced completeness of learning outcomes so that the research was stopped. Based on these data, it can be concluded that Proshow Gold video-based learning media can improve critical thinking skills and learning outcomes in 4th grade students of SD Negeri 3 Mangaran, Situbondo Regency.

Keywords: Proshow Gold video, instructional media, critical thinking, learning outcomes 


\section{Pendahuluan}

Pembelajaran yang menghendaki siswa untuk dapat mengembangkan kemampuan berpikir kritis, membutuhkan peranan adanya pemilihan dan penggunaan berbagai perangkat pembelajaran khususnya media pembelajaran. Media pembelajaran menempati posisi yang cukup penting sebagai salah satu komponen pembelajaran. Komunikasi tidak akan terjadi tanpa media dan proses pembelajaran sebagai proses komunikasi juga tidak akan bisa berlangsung secara optimal. Proses pembelajaran terdapat beberapa persoalan, yaitu pelaksanaan pembelajaran tematik dirasa sangat belum optimal, penggabungan materi dari beberapa muatan pelajaran menjadi satu tema pembelajaran masih kurang sesuai, pembelajaran yang berlangsung masih didominasi oleh aktivitas guru, proses pembelajaran yang kurang menarik, sehingga sebagian besar siswa tidak memperhatikan penjelasan dari guru. Penyampaian materi dilakukan dengan metode ceramah, Siswa belum dapat menyampaikan ide-ide ataupun sarannya, pergantian pelajaran menuju ke pelajaran berikutnya masih terlihat jelas. Hal ini disebabkan perpaduan muatan pelajaran yang kurang tepat. Guru belum bisa menciptakan suasana pembelajaran yang kondusif, motivasi belajar yang dimiliki siswa rendah, tidak terlihat adanya penggunaan media pembelajaran bahkan media pembelajaran yang menarik, yaitu guru menggunakan media papan tulis serta penggaris ketika mengajar. Media tersebut sudah sering digunakan oleh guru, sehingga menimbulkan rasa bosan pada siswa yang menyebabkan siswa belum dapat mengingat materi dengan baik

Pembelajaran masih berpusat pada guru, sehingga siswa hanya menjadi pendengar yang baik dan pengetahuan yang mereka dapatkan hanyalah pengetahuan yang ditransfer dari seorang guru sehingga konsep yang didapatkan bersifat hayalan saja bukan hasil dari pengalaman yang dimiliki para siswa sendiri. Hal tersebut berpengaruh terhadap kemampuan berpikir kritis siswa yang pada akhirnya akan berpengaruh terhadap hasil belajar siswa. Dari 19 siswa kelas IV, rata-rata aktivitas siswa sebesar 36 $\%$ atau tergolong siswa sangat pasif.

Salah satu media pembelajaran yang dapat menjadi alternatif adalah media pembelajaran berbasis video Proshow Gold. Pembelajaran dengan media pembelajaran video Proshow Gold adalah proses pembelajaran yang dirancang sedemikian rupa agar peserta didik secara aktif mengkontruksi konsep, hukum atau prinsip melalui tahapan- 
tahapan mengamati (untuk mengidentifikasi atau menemukan masalah) kemudian mengkomunikasikan konsep yang telah diperoleh dari kegiatan mengamati. Media pembelajaran berbasis video Proshow Gold ini juga mampu membantu siswa untuk mengatasi keterbatasan jarak dan waktu tentang materi yang diajarkan. Siswa juga diajak untuk berimajinasi sehingga dapat meningkatkan pola berpikir kritis siswa, karena siswa dikondisikan untuk mengamati dan memahami konsep yang sedang dilihatnya.

Beberapa hal yang harus diperhatikan sebelum membuat video pembelajaran dari software Proshow Gold adalah mempersiapkan segala sesuatu yang diperlukan, mulai dari materi yang akan disajikan, gambar-gambar penunjang pembuatan video, musik yang sesuai dan perencanaan sistematika urutan materi. Hal yang paling tidak dapat ditinggalkan adalah menentukan kompetensi dasar materi yang akan digunakan. Berikut akan disajikan bagaimana membuat video menggunakan Proshow Gold. Langkahlangkahnya yaitu :

1. Klik $2 \mathrm{x}$ icon Photodex Proshow Gold di layar desktop Anda. Kita akan melihat jendela utama Photodex Proshow Gold

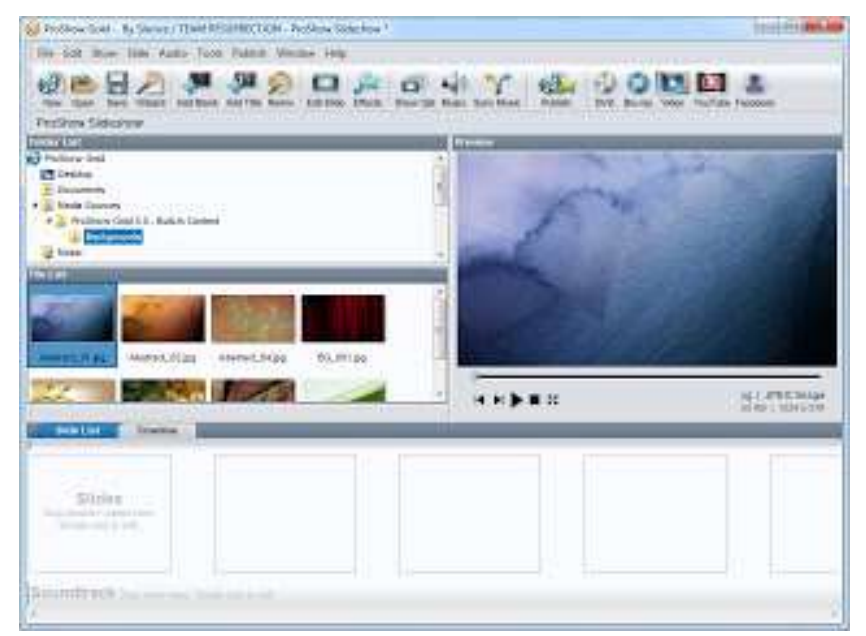

2. Klik icon Add Title yang ada di Toolbar. Maka akan terlihat seperti jendela di bawah ini

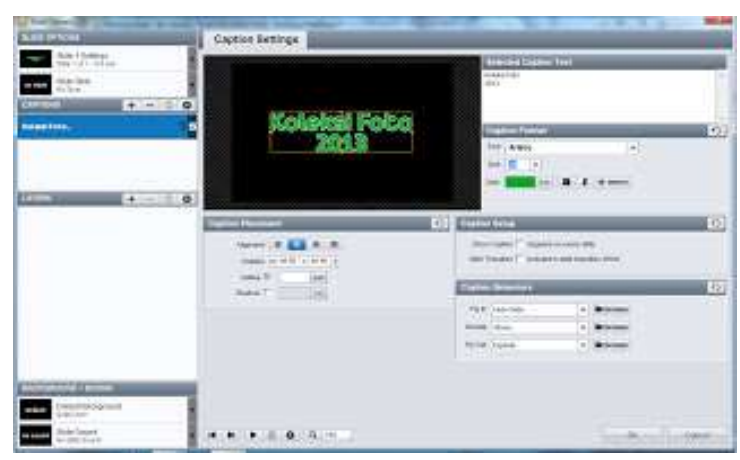


3. Buatlah teks seperti pada contoh di atas. Atau Anda juga bisa membuat teks sesuai keinginan sendiri dengan memilih berbagai efek yang tersedia. Lalu klik tombol OK.

a. Maka pada timeline akan terlihat nanti tambahan objek, yaitu objek teks atau judul.

b. Kemudia pada layar utama, pilihlah beberapa gambar yang akan dijadikan slideshow. Seperti terlihat pada gambar

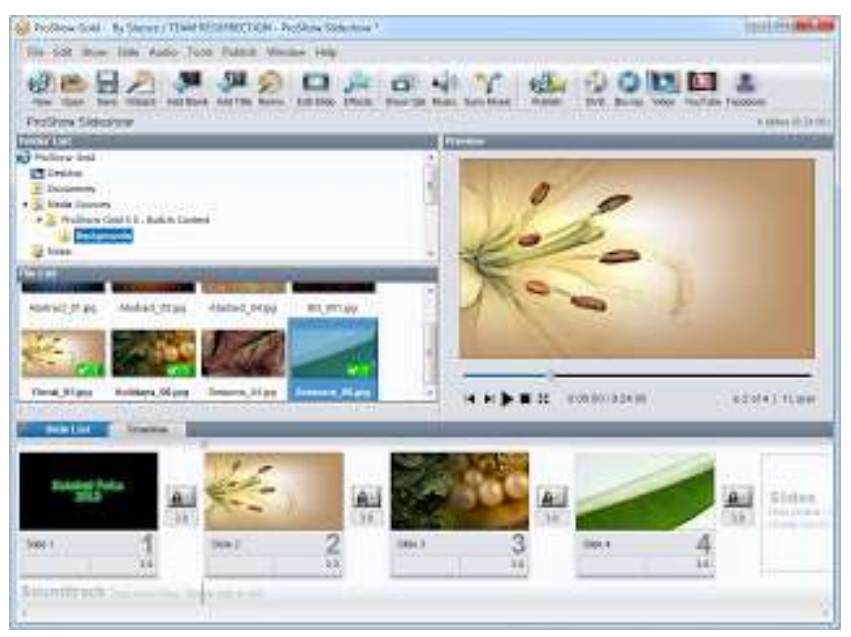

4. Untuk memasukkan gambar ke dalam timeline, drag lah gambar tersebut ke dalam timeline. Lakukan langkah yang sama untuk gambar-gambar berikutnya.

5. Selanjutnya adalah memberikan efek transisi pada gambar. Klik tombol Efek Transisi pada timeline seperti terlihat pada gambar, kemudian pilihlah salah satu efek yang sesuai. Seperti terlihat pada gambar.

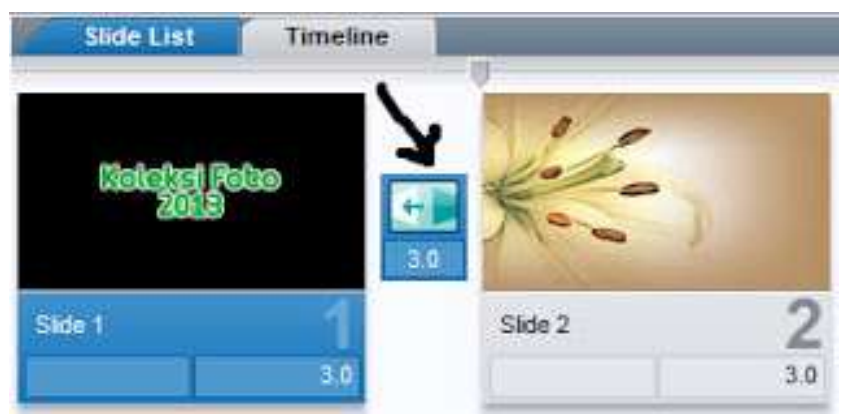


6. Pilih salah satu efek, kemudian klik tombol Apply

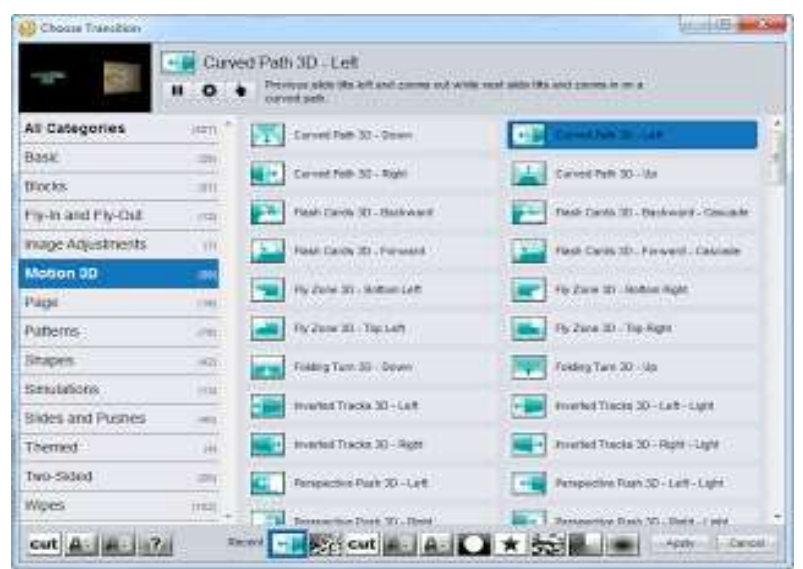

7. Berikutnya adalah mempublish selideshow. Klik tombol Publish pada toolbar, seperti gambar di bawah.

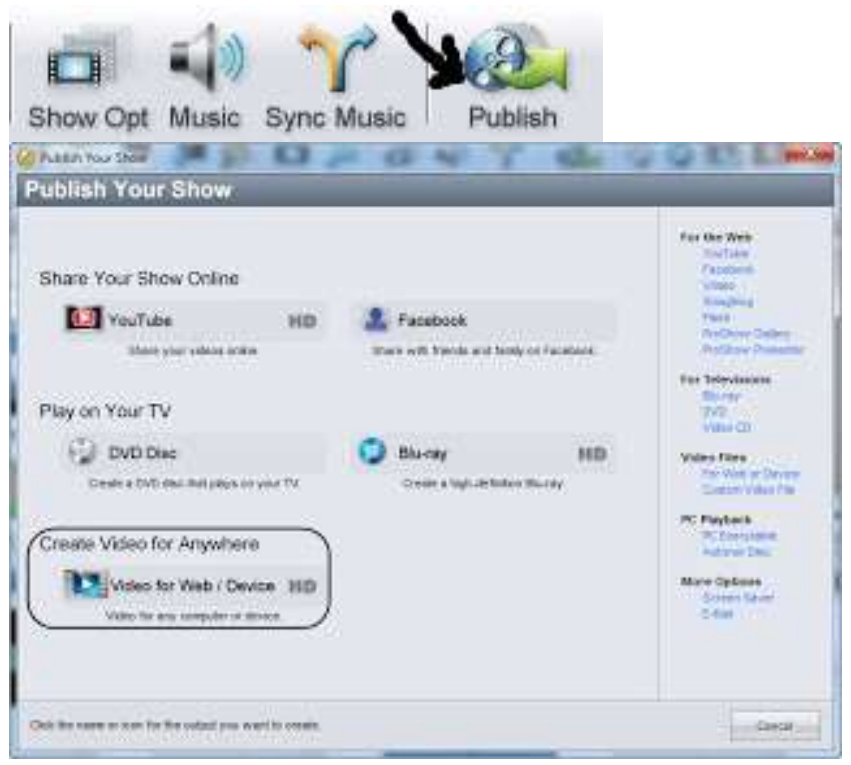

8. Selanjutnya pilih Creative Video for Anywhere

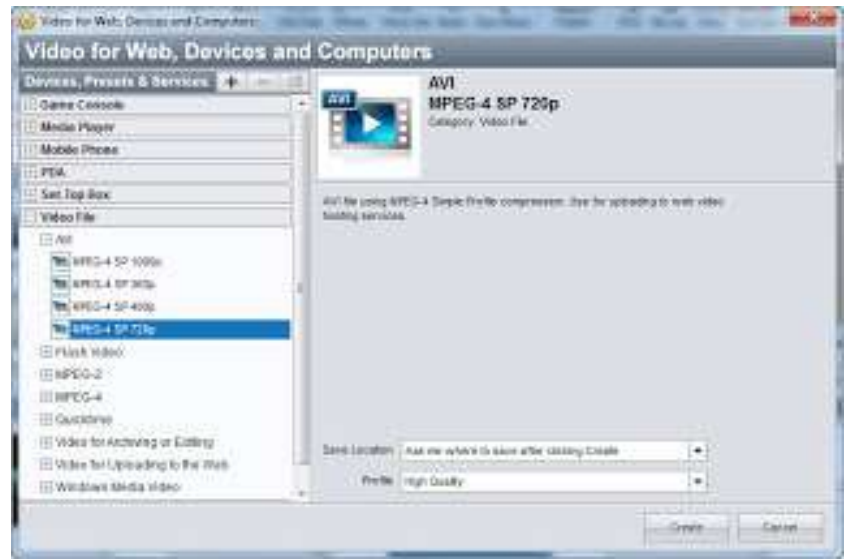


9. Pada Devices, Presets \& Service pilih format video file MPEG-4 720p. Lalu klik tombol Create

10. Salanjutnya akan diminta untuk menyimpan file video tersebut. Berikanlah nama file untuk video yang Anda buat.

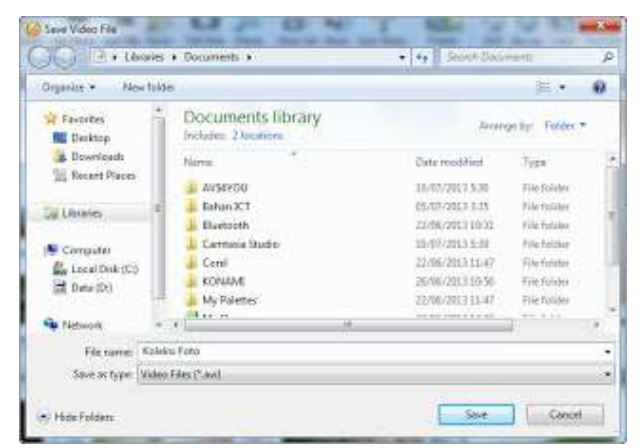

11. Setelah itu akan muncul proses rendering video. Tunggu sampai proses rendernya selesai.

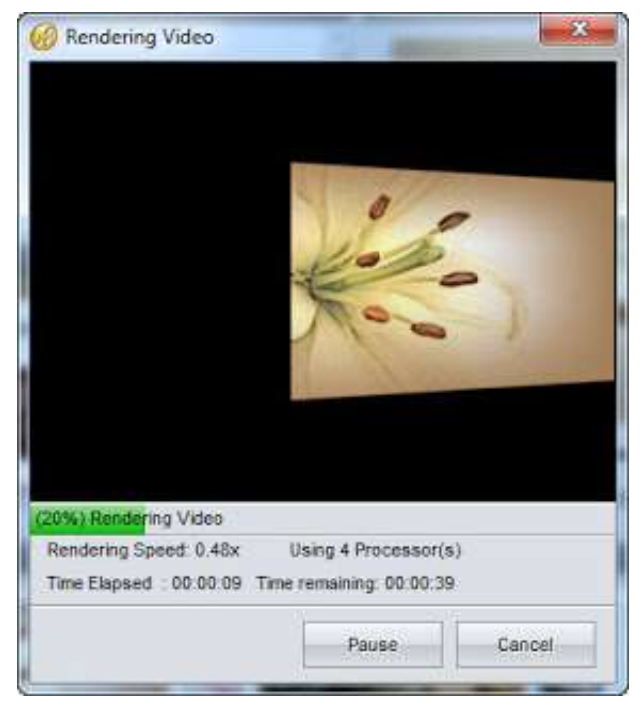

\section{Metode Penelitian}

Metode penelitian yang dilakukan adalah penelitian tindakan(action research) Penelitian tindakan Kemmis \& Mc Taggart (dalam Arikunto, 2006:132) ini meliputi empat tahap yaitu (1) perencanaan (planning), (2) tindakan (action), (3) pengamatan (observation), (4) refleksi (reflection). Pada model Kemmis \& Taggart tindakan (acting) dan observasi (observing) dijadikan sebagai satu kesatuan karena mereka menganggap bahwa kedua komponen tersebut merupakan dua kegiatan yang tidak bisa dipisahkan. Keberhasilan secara klasikal mengikuti standar George E. Mills (2003:96) dalam penelitiannya yaitu menetapkan persentase $71 \%$. 
Teknik yang digunakan untuk mengumpulkan data dalam penelitian ini adalah: (1) Teknik Observasi, (2) Teknik Wawancara, (3) Teknik Dokumentasi dan (4) Teknik Tes. Data yang diperoleh dari kegiatan observasi yaitu data tentang kemampuan berpikir kritis dan hasil belajar siswa kelas IV SD Negeri 3 Mangaran selama proses pembelajaran berlangsung. Hasil observasi digunakan untuk melakukan refleksi pada akhir siklus. Observer dalam penelitian ini adalah peneliti dan teman sejawat. Instrumen observasi berupa lembar observasi. Teknik wawancara dilakukan untuk memperoleh data tentang pengalamannya dalam pembelajaran tematik mengunakan media yang sering dipakai. Dalam penelitian ini data yang ingin diperoleh dengan dokumentasi adalah daftar nama siswa kelas IV yang menjadi subyek penelitian, silabus, jadwal pelajaran dan nilai pre test. Tes dalam penelitian ini digunakan untuk mengukur kemampuan siswa dalam memahami dan menguasai materi. Jenis tes yang digunakan dalam tes formatif yang dilakukan setelah pembelajaran selesai.

Data yang diperoleh dalam penelitian ini dianalisis dengan menggunakan model analisis deskriptif presentase. Hasil observasi, wawancara dan tes dikaji untuk mengetahui tindak lanjut yang dapat dilakukan terhadap aktivitas guru saat pembelajaran dengan memanfaatkan media pembelajaran berbasis video Proshow Gold serta untuk mengetahui peningkatan berpikir kritis dan hasil belajar siswa.

Jenis data yang digunakan dalam penelitian adalah data kualitatif dan data kuantitatif. Data Kualitatif, yaitu data yang disajikan dalam bentuk kata verbal bukan dalam bentuk angka. Yang termasuk data kualitatif dalam penelitian ini yaitu gambaran umum obyek penelitian, meliputi: aktivitas belajar siswa di kelas, penggunaan media pembelajaran di sekolah, teknik guru dalam menyampaikan pembelajaran (keadaan guru) dan keefektivitas pembelajaran. Data Kuantitatif adalah jenis data yang dapat diukur atau dihitung secara langsung, yang berupa informasi atau penjelasan yang dinyatakan dengan bilangan atau bentuk angka. Dalam hal ini data kuantiatif yang diperlukan dalam penelitian ini adalah: jumlah guru, jumlah siswa dan hasil tes.

\section{Hasil dan Pembahasan}

Pada bagian ini memaparkan tentang hasil penelitian mulai dari pra siklus meliputi observasi dari aktivitas belajar, kemampuan berpikir kritis dan aktivitas guru selama proses pembelajaran. Kemudian dari pra siklus dilanjutkan pada siklus 1 dan 
siklus 2 meliputi perencanaan, pelaksanaan tindakan, observasi yang terbagi menjadi 3 yaitu aktivitas belajar siswa, kemampuan berpikir kritis dan aktivitas guru dalam memanfaatkan media pembelajaran berbasis video Proshow Gold serta diakhir terdapat kegiatan refleksi.

\section{Pra siklus}

Pelaksanaan kegiatan pra siklus dalam penelitian ini dilakukan dengan mengobservasi dan mengumpulkan data terkait dengan kondisi sekolah, jumlah siswa, hasil belajar siswa, kemapuan berpikir kritis siswa, dan media pembelajaran yang digunakan dalam proses pembelajaran pada materi di tema perkembangan teknologi, subtema perkembangan teknologi pangan di kelas III SDN 3 Mangaran Situbondo serta kendala-kendala yang ditemui selama melangsungkan kegiatan belajar mengajar antara guru dan siswa.

Dari wawancara dan observasi dapat diketahui bahwa dalam menyampaikan materi, selama ini guru hanya menggunakan metode konvensional dikarenakan kemampuan paedagogik khususnya pemanfaatan media pembelajaran serta pengetahuan akan bermacam-macam metode, model dan strategi pembelajaran yang rendah. Dalam metode konvensional guru tidak memberi kesempatan kepada siswa untuk menggali dan menemukan kebenaran konsep setiap materi yang dipelajari. Siswa hanya mendengarkan penjelasan dari guru dan hanya menghafal materiyang diberikan oleh guru melalui metode ceramah.

Berdasarkan hasil dari kegiatan observasi, dapat diketahui bahwa aktivitas guru selama proses pembelajaran di dalam kelas dikategorikan kurang terampil. Setelah melalui penghitungan, aktivitas guru pada tahap ini memperoleh nilai presentase sebesar $36 \%$ yang artinya guru tidak terampil dalam melakukan pembelajaran di kelas.

Berdasarkan hasil dari kegiatan observasi pra siklus ini, dapat diketahui bahwa aktivitas siswa di kelas IV SDN 3 Mangaran pada tema perkembangan teknologi, subtema perkembangan teknologi pangan khususnya dalam berpikir kritis dikategorikan sangat rendah. Pada pra siklus ini, peneliti juga melakukan observasi terhadap hasil belajar siswa. Berdasarkan nilai-nilai ulangan yang diperoleh siswa kelas IV di SDN 3 Mangaran pada tema sebelumnya, separuh lebih dari jumlah siswa memperoleh nilai di bawah KKM yang telah ditentukan oleh sekolah. Hanya 5 siswa yang memperoleh nilai 
di atas KKM, itupun tidak jauh di atas nilai KKM. Hasil belajar siswa dalam bentuk ulangan

\section{Siklus 1}

Pada siklus 1 ketika proses pembelajaran, guru dalam mengasah kemampuan berpikir kritis siswa mengalami beberapa kendala, yaitu siswa masih terlihat ramai dan sibuk sendiri, siswa masih bersifat individu dalam kelompok, siswa masih kurang percay a diri dan takut dalam mengungkapkan pendapat ataupun argument yang dimiliki. po pulasi siswa yang mulai berpikir kritis dan belum berpikir kritis akan disajikan pada tabel di bawah ini:

Tabel 1. Berpikir Kritis Siswa Siklus 1

\begin{tabular}{|c|l|c|c|c|c|}
\hline No. & \multicolumn{1}{|c|}{ Siswa } & KKM & Nilai & $\begin{array}{c}\text { Jumlah } \\
\text { Siswa }\end{array}$ & Persentase \\
\hline 1. & Jumlah siswa berpikir kritis & 65 & $\geq 65$ & 12 & $63 \%$ \\
\hline 2. & Jumlah siswa tidak tuntas & 65 & $<65$ & 7 & $37 \%$ \\
\hline \multicolumn{2}{|l}{ Jumlah } & 19 & $100 \%$ \\
\hline
\end{tabular}

Berdasarkan tabel di atas terjadi peningkatan jumlah siswa berpikir kritis dari pra siklus ke siklus 1 yang pada mulanya hanya 4 siswa yang berpikir kritis sekarang menjadi 12 siswa dengan presentase 63\%. Untuk siswa yang belum berpikir kritis sebanyak 7 orang siswa dengan presentase $37 \%$.

Berdasarkan evalusi materi yang telah di ajarkan selama dua pertemuan ini digunakan peneliti untuk mengetahui peningkatan hasil belajar siswa. Presentase siswa yang tuntas dalam ulangan harian dan belum tuntas dalam ulangan harian disajikan pada tabel berikut ini:

Tabel 2 Hasil Belajar Siswa Siklus 1

\begin{tabular}{|c|l|c|c|c|c|}
\hline No. & \multicolumn{1}{|c|}{ Siswa } & KKM & Nilai & $\begin{array}{c}\text { Jumlah } \\
\text { Siswa }\end{array}$ & Persentase \\
\hline 1. & Jumlah siswa tuntas & 65 & $\geq 65$ & 13 & $68 \%$ \\
\hline 2. & Jumlah siswa tidak tuntas & 65 & $<65$ & 6 & $32 \%$ \\
\hline \multicolumn{7}{|l|}{ Jumlah } & 19 & $100 \%$ \\
\hline
\end{tabular}


Dari pra siklus hanya sebanyak 6 orang siswa yaitu sebesar $46 \%$ yang dikategorikan tuntas mengikuti ulangan harian, sedangkan pada siklus 1 terdapat 13 orang siswa dengan presentase $68 \%$ yang dikategorikan tuntas mengikuti ulangan harian.

\section{Siklus 2}

Selama proses pembelajaran, guru dalam mengasah kemampuan berpikir kritis siswa telah mengalami kemajuan. Siswa lebih mudah untuk diarahkan atau dihadapkan kepada sebuah masalah untuk di selesaikan. Percaya diri mulai muncul dan rasa takut berangsur-angsur tidak terlihat. Siswa lebih aktif berpendapat dan menanggapi sebuat argumen yang disampaikan oleh temannya. Diskusi dalam kelompok kecil terlihat lebih kondusif, siswa saling tolong-menolong memberikan penjelasan kepada teman yang belum memahami materi yang sedang diajarkan/dibahas. Sedangkan populasi siswa yang mulai berpikir kritis dan belum berpikir kritis akan disajikan pada tabel di bawah ini:

Tabel 3. Berpikir Kritis Siswa Siklus 2

\begin{tabular}{|c|l|c|c|c|c|}
\hline No. & \multicolumn{1}{|c|}{ Siswa } & KKM & Nilai & $\begin{array}{c}\text { Jumlah } \\
\text { Siswa }\end{array}$ & Persentase \\
\hline 1. & Jumlah siswa berpikir kritis & 65 & $\geq 65$ & 16 & $84 \%$ \\
\hline 2. & Jumlah siswa tidak tuntas & 65 & $<65$ & 3 & $16 \%$ \\
\hline \multicolumn{7}{|l}{ Jumlah } & 19 & $100 \%$ \\
\hline
\end{tabular}

Berdasarkan tabel di atas terjadi peningkatan jumlah siswa berpikir kritis dari siklus 1 ke siklus 2 yang pada mulanya hanya 12 siswa yang berpikir kritis sekarang menjadi 16 siswa dengan presentase $84 \%$. Untuk siswa yang belum berpikir kritis sebanyak 3 orang siswa dengan presentase $16 \%$.

Berdasarkan evalusi materi yang telah di ajarkan selama dua pertemuan ini digu nakan peneliti untuk mengetahui peningkatan hasil belajar siswa. Setelah dianalisis dan dinilai, hasil ulangan siswa kelas IV pada materi perkembangan teknologi, subtema perkembangan teknologi pangan pembelajaran 4 dan 5 mengalami peningkatan dari pembelajaran 1 dan pembelajaran 2 di siklus 1 . Dari siklus 1 hanya sebanyak 13 orang siswa yang dikategorikan tuntas men giku ti 
ulangan harian, sedangkan pada siklus 2 terdapat 17 orang siswa dengan presenta se $89 \%$ y ang dikategorikan tuntas mengikuti ulangan harian. Nilai siswa dalam ulangan harian terlih at lebih bagus dari nilai di siklus 1. Kesalahan-kesalahan siswa lebih sedikit, begitupun untuk siswa yang belum tuntas. Presentase siswa yang tuntas dalam ulangan harian dan belum tuntas dalam ulangan harian disajikan pada tabel berikut ini:

Tabel 4. Hasil Belajar Siswa Siklus 2

\begin{tabular}{|c|l|c|c|c|c|}
\hline No. & \multicolumn{1}{|c|}{ Siswa } & KKM & Nilai & $\begin{array}{c}\text { Jumlah } \\
\text { Siswa }\end{array}$ & Persentase \\
\hline 1. & Jumlah siswa tuntas & 65 & $\geq 65$ & 17 & $89 \%$ \\
\hline 2. & Jumlah siswa tidak tuntas & 65 & $<65$ & 2 & $11 \%$ \\
\hline Jumlah & 19 & $100 \%$ \\
\hline
\end{tabular}

\section{Pembahasan}

Berdasarkan hasil analisis nilai soal kuis dalam menguji kemampuan berpikir kritis siswa dalam kegiatan belajar mengajar yang berlangsung dari pra siklus, siklus 1 sampai siklus 2 diperoleh data seperti pada grafik berikut ini:

Gambar 5. Grafik Perbandingan Kemampuan Berpikir Kritis Siswa

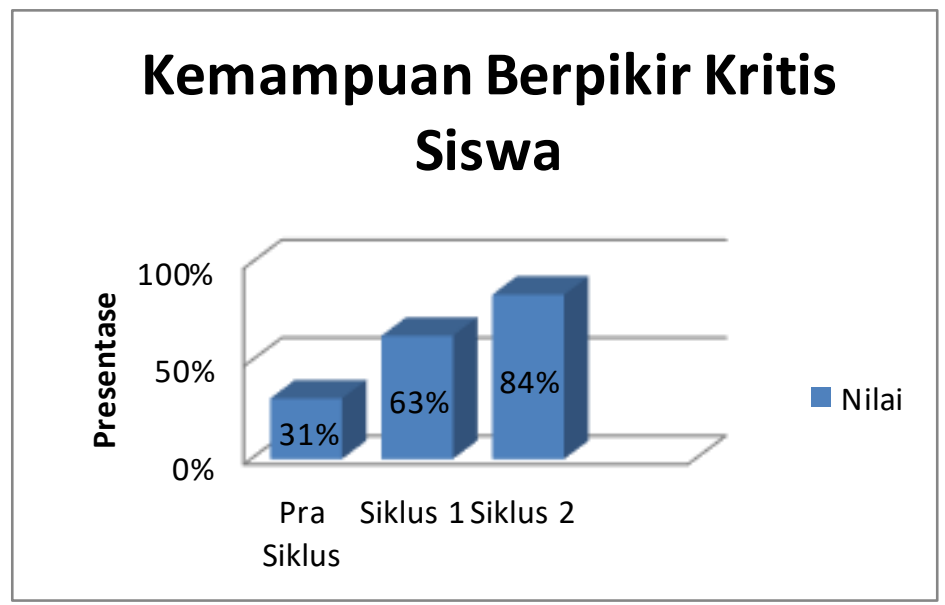


Sedangkan hasil analisis nilai ulangan harian dalam menguji hasil belajar siswa dalam kegiatan belajar mengajar yang berlangsung dari pra siklus, siklus 1 sampai siklus 2 diperoleh data seperti pada grafik berikut ini:

Gambar 4.3 Grafik Perbandingan Hasil Belajar Siswa

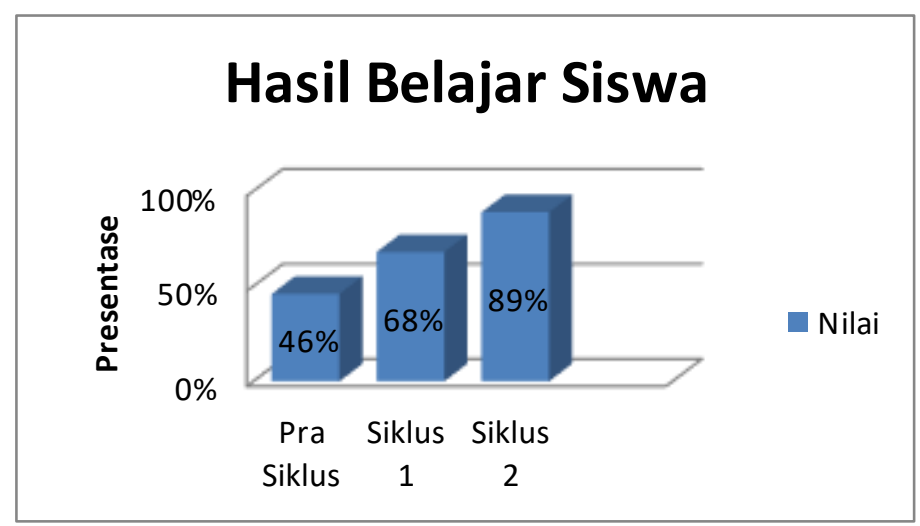

\section{Kesimpulan}

Penelitian tindakan Kelas (PTK) ini telah dilaksanakan bagi siswa kelas IV dalam 2 siklus dengan 3 pertemuan pada masing-masing siklus. Setiap siklus terdiri dari empat tahapan, yaitu: (1) perencanaan, (2) pelaksanaan tindakan, (3) observasi, dan (4) refleksi. Berdasarkan pembahasan dan hasil penelitian maka dapat disimpulkan sebagai berikut: pembelajaran pada tema perkembangan teknologi, subtema perkembangan teknologi pangan melalui pemanfaatan media pembelajaran berbasis video Proshow Gold untuk aktivitas guru pada siklus 1 sebesar 61\% dengan kategori terampil. Kemudian pada siklus 2 mengalami peningkatan dengan presentase $79 \%$ dalam kategori sangat terampil. Dari presentase tersebut maka dapat diketahui aktivitas guru mengalami peningkatan sebesar $8 \%$ dari siklus 1 ke siklus 2.

Pemanfaatan media pembelajaran berbasis video Proshow Gold dalam pembelajaran dapat meningkatkan kemampuan berpikir kritis dan hasil belajar siswa. Hasil perolehan presentase untuk kemampuan berpikir kritis siswa mulai dari pra siklus sebesar 36\%, siklus 1 sebesar 63\%, dan siklus 2 sebesar $84 \%$. Sedangkan untuk hasil belajar siswa muali dari pra siklus sebesar $46 \%$, siklus 1 sebesar $68 \%$, dan siklus 2 sebesar $89 \%$. 


\section{Daftar Pustaka}

Arikunto, Suharmisi. Prosedur Penelitian Suatu Pendekatan Praktis, Jakarta : Rineka cipta, 2008.

Filsaime, K. D. (2007). Menguak Rahasia Berpikir Kritis dan Kreatif. Jakarta: Prestasi Pustaka.

Hamdani, M.A. 2011. Strategi Belajar Mengajar. Bandung: Pustaka Setia

Harahap, I. 2011. Keaktifan Belajar. Diperoleh tanggal 28 April 2016, dari http://irpan1990.word press.com/2011/08/11/keaktifan-belajar/

Harsanto, Radno. 2005. Melatih Anak Berpikir Analitis, Kritis, dan Kreatif. Jakarta: Grasindo.

Mulyana, E. 2005. Menjadi Guru Profesional. Bandung: Remaja Rosdakarya.

Pudjiastuti, Ari. 2011. "Permasalahan Penerapan Pembelajaran Tematik di Kelas Awal Sekolah Dasar”. Tidak diterbitkan. Tesis. Malang: Universitas Negeri Malang. 